\title{
PEMBERDAYAAN EKONOMI ANGGOTA UNIT JASA KEUANGAN SYARIAH MELALUI PRODUK SIMPANAN DAN PEMBIAYAAN DI UNIT SIMPAN PINJAM DAN PEMBIAYAAN SYARIAH
}

\author{
AS-SAKINAH SURABAYA')
}

\author{
M. Haris Hidayatulloh \\ Program Studi S1 Ekonomi Islam-Fakultas Ekonomi dan Bisnis-Universitas Airlangga \\ Email : harishidayat69@gmail.com \\ Moh. Qudsi Fauzi \\ Departemen Ekonomi Syariah-Fakultas Ekonomi dan Bisnis-Unversitas Airlangga \\ Email : qudsifauzy1@gmail.com
}

\begin{abstract}
:
Islamic finances cooperation/Islamic finances servise unit as one of micro organization that has a role in developing and evolving the economical potential of its members in particular way, and the society in general way, to increase the economical and social prosperity.

The aim of this research is to find out the role of Islamic finances cooperation unit in empowering the economies of its member. This researce is using the qualitative approach by case study as a strategy. The data collection is achieved by interviewing the related objects directly.

This research indicated that the members experienced the role of Islamic savings and loan and budgeting unit of As-Sakinah Surabaya helpfully by offering its finances products, namely the deposit and the budgeting with many models upon the members fancies and the most important part of the460products is, the contracts are based on the Islamic law.

Keywords: Islamic Finances Cooperation, Economical Empowering, Islamic Saving And Loan And Budgeting Unit of As-Sakinah
\end{abstract}

\section{PENDAHULUAN}

Indonesia memiliki dualisme sistem kevangan yang berbeda yaitu sistem konvensional dan sistem syariah. Koperasi Syariah juga memiliki pengertian yang sama dengan kegiatan usaha yang sama pula (pembiayaan, investasi, dan simpanpinjam) namun berbeda pada pengelolaan dan pembagian hasil usahanya. Pada koperasi konvensional menggunakan sistem bunga, sedangkan pada Koperasi Syariah menggunakan sistem bagi hasil hal ini disesuaikan dengan ajaran agama islam guna menjauhi praktik ribawi. Dalam Al-Quran telah disebutkan pengharaman atas riba yaitu pada QS. Al-Baqarah: 275.

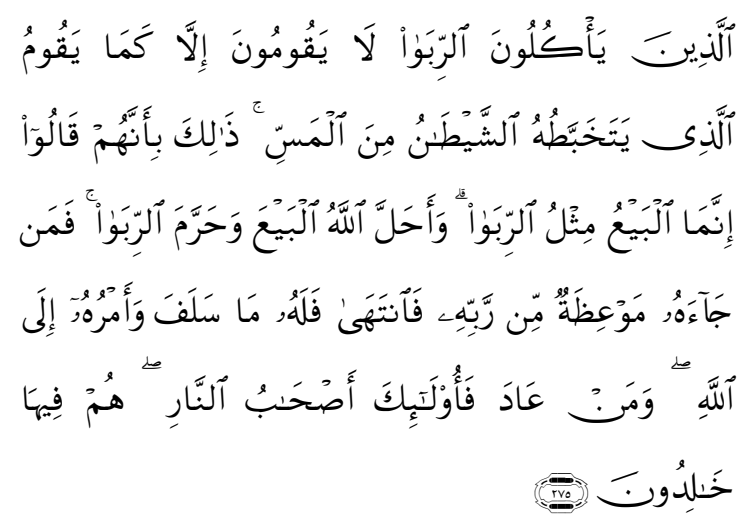

Allaz $\backslash>>n a$ ya'kulu>nar-riba> la> yaqu>mu>na illa> kama> yaqu>mullazi yatakhabbat\}uhus syait\}a>nu minal-mass, zla>lika bi'annahum $q a>l u>\quad$ innamal-ba'u mis\ur-riba>, wa ahallalla>hul-bai'a wa h\}arramar-riba>, fa man ja>'ahu> mau'iz\}atum mir rabbihi> fantaha> fa lahu> ma> salaf, wa amruhu> ilalla>h, wa man

'Jurnal ini merupakan bagian dari skripsi dari nama penulis pertama, NIM : 041114032 yang diuji pada 09 Februari 2016 
Hidayatulloh, et al/Jurnal Ekonomi Syariah Teori dan Terapan Vol. 3 No. 6 Juni 2016: 460-473; PEMBERDAYAAN EKONOMI ANGGOTA UNIT JASA KEUANGAN SYARIAH MELALUI PRODUK SIMPANAN DAN PEMBIAYAAN DI UNIT SIMPAN PINJAM DAN PEMBIAYAAN SYARIAH AS-SAKINAH SURABAYA

' $a>$ da fa ula> 'ika as\}-h\}a>bun-na>r, hum fi>ha> kha>lidun.

Artinya: "Orang-orang yang Makan (mengambil) riba tidak dapat berdiri melainkan seperti berdirinya orang yang kemasukan syaitan lantaran (tekanan) penyakit gila. Keadaan mereka yang demikian itu, adalah disebabkan mereka berkata (berpendapat), Sesungguhnya jual beli itu sama dengan riba, Padahal Allah telah menghalalkan jual beli dan mengharamkan riba. orang-orang yang telah sampai kepadanya larangan dari Tuhannya, lalu terus berhenti (dari mengambil riba), Maka baginya apa yang telah diambilnya dahulu (sebelum datang larangan); dan urusannya (terserah) kepada Allah. orang yang kembali (mengambil riba), Maka orang itu adalah penghuni-penghuni neraka; mereka kekal di dalamnya" (Al-Baqarah : 275).

Koperasi Syariah atau yang lebih dikenal dengan Koperasi Jasa Keuangan Syariah (KJKS) memiliki aturan yang relatif sama dengan koperasi umum (konvensional), namun yang membedakannya adalah produk-produk yang ada di koperasi umum diganti dan disesuaikan nama dan sistemnya dengan tuntunan dan ajaran agama islam. Adapun produk koperasi umum jual-beli dan simpan-pinjam yang berganti nama menjadi murabahah dan mudharabah pada Koperasi Jasa Kevangan Syariah. Tidak hanya nama yang berubah namun sistem operasionalnya juga berubah sesuai dengan aturan agama islam. Namun terdapat sebagian Koperasi Syariah yang membentuk unit usaha sehingga koperasi tersebut terfokus pada kegiatan koperasi saja. Unit ini dinamakan sebagai Unit Jasa Keuangan Syariah (UJKS).

Unit Jasa Keuangan Syariah (UJKS) ini di bentuk dengan tujuan memfokuskan pada produk koperasi di bidang usaha pembiayaan, investasi, dan simpanan. Menurut Peraturan Menteri Negara Koperasi dan Usaha Kecil Dan Menengah Nomor 35.2 /Per/M.KUKM/X/2007 tanggal 5 Oktober 2007 tentang Pedoman Standar Operasional Manajemen Koperasi Jasa Keuangan Syariah dan Unit Jasa Keuangan Syariah Koperasi, Unit Jasa Keuangan Syariah (UJKS) adalah unit usaha pada Koperasi yang kegiatan usahanya bergerak di bidang pembiayaan, investasi, dan simpanan sesuai dengan pola bagi hasil (syariah), sebagai bagian dari kegiatan usaha Koperasi yang bersangkutan.

Dari pemaparan terkait koperasi diatas dapat kita ketahui bahwa koperasi memiliki keterkaitan terhadap dua unsur berbeda yaitu unsur ekonomi dan unsur sosial. Sebagai salah satu bentuk dari berbagai bentuk lembaga keuangan yang ada, koperasi seharusnya mengupayakan secara maksimal pada pemenuhan kebutuhan ekonomi para anggotanya secara efisien. Sedangkan unsur sosial dapat digambarkan bahwa koperasi merupakan suatu wadah bagi masyarakat untuk berkumpul bersama tanpa menghiraukan berbagai perbedaan pada masing-masing mereka untuk mewujudkan tujuan bersama dari 
Hidayatulloh, et al/Jurnal Ekonomi Syariah Teori dan Terapan Vol. 3 No. 6 Juni 2016: 460-473; PEMBERDAYAAN EKONOMI ANGGOTA UNIT JASA KEUANGAN SYARIAH MELALUI PRODUK SIMPANAN DAN PEMBIAYAAN DI UNIT SIMPAN PINJAM DAN PEMBIAYAAN SYARIAH AS-SAKINAH SURABAYA

koperasi yaitu mencapai kesejahteraan. Dari sisi lain dapat kita lihat bahwa koperasi memiliki hubungan dengan ekonomi kerakyatan, sebagaimana kita tahu ekonomi kerakyatan dikenal sebagai paham ekonomi yang berpihak pada rakyat (rakyat kalangan menengah kebawah).

Pada kenyataannya terdapat kendala yang cukup serius pada pembangunan masyarakat yaitu permasalahan kemiskinan. Pada dasarnya permasalahan kemiskinan melanda masyarakat atas ketidak berdayaannya dalam mengakses informasi atau kemampuan yang berkaitan dengan aspek ekonomi, sosial serta aspek politik, oleh karenannya pemberdayaan ekonomi masyarakat dinilai sebagai poin utama dalam rangka mengentaskan permasalahan kemiskinan ini. Dalam Kamus Besar Bahasa Indonesia pemberdayaan adalah upaya membuat suatu kemampuan atau berkekuatan, dengan demikian pemberdayaan anggota merupakan upaya untuk memandirikan agar memiliki kemampuan dan kekuatan. Selanjutnya tujuan pemberdayaan menurut Santoso (2008) adalah bekerja bersama masyarakat sehingga masyarakat dapat mendefinisikan dan menangani masalah, dan terbuka untuk mengekspresikan kepentingan mereka sendiri dalam proses pengambilan keputusan.
Bila kita amati keberadaan lembaga keuangan mikro (Koperasi Syariah/Unit Jasa Kevangan Syariah) merupakan jalan efektif dalam membantu dan memberdayakan anggotanya dan meningkatkan ekonomi keluarga. Hadirnya Koperasi Syariah /Unit Jasa Keuangan Syariah adalah sebagai sarana yang baik dalam pengentasan kemiskinan yaitu sebagai suatu model penyedia jasa keuangan bagi masyarakat yang masih belum bisa mengakses dunia perbankan karena adanya berbagai macam keterbatasan.

Pada tahun 2007, berawal dari beberapa anggota yang membutuhkan modal usaha, baik dalam bentuk modal inventory ataupun modal uang, maka pengurus berinisiatif untuk memulai pengembangan usaha dibidang simpan pinjam dengan berbasis syariah dan mulai mengakomodir kebutuhan keuangan anggota. Usaha ini pada awalnya hanya dikelola secara sederhana dan tanpa pengelolaan khusus, pada tahun 2010 dengan melihat animo anggota pada pada segmen simpan pinjam mulai besar maka ditempatkan satu orang karyawan untuk mengelola secara khusus usaha simpan pinjam. Pada tahun 2011 upaya pengembangan terus dilakukan, baik secara sistem ataupun produk, pada tahun ini terjadi perubahan penamaan lembaga sesuai surat edaran dari Kementrian Koperasi Dan UMKM menjadi unit simpan pinjam dan pembiayaan 
Hidayatulloh, et al/Jurnal Ekonomi Syariah Teori dan Terapan Vol. 3 No. 6 Juni 2016: 460-473; PEMBERDAYAAN EKONOMI ANGGOTA UNIT JASA KEUANGAN SYARIAH MELALUI PRODUK SIMPANAN DAN PEMBIAYAAN DI UNIT SIMPAN PINJAM DAN PEMBIAYAAN SYARIAH AS-SAKINAH SURABAYA

syariah (USPPS) serta terjadi pula sistem pengelolaan mulai mengunakan sistem komputerisasi dan berbagai pengembangan yang terus dilakukan hingga sekarang.

Dari berbagai pemaparan diatas bahwa Koperasi Syariah/Unit Jasa Keuangan Syariah sebagai salah satu bentuk dari Lembaga Keuangan Mikro yang lebih memfokuskan sasarannya pada pemberdayaan ekonomi anggota dengan tujuan mampu meningkatkan kondisi perekonomiannya. Melihat pada kedekatan konsep Unit Jasa Keuangan Syariah (UJKS) dengan pemberdayaan ekonomi maka penulis tertarik untuk mengkaji dan meneliti lebih dalam lagi terkait dengan Unit Jasa Keuangan Syariah (UJKS) dan pemberdayaan anggotanya melalui berbagai produk kevangan yang ditawarkan.

\section{LANDASAN TEORI}

\section{Unit Jasa Keuangan Syariah}

Unit Jasa Keuangan Syariah (UJKS) merupakan unit usaha Koperasi Syariah yang bergerak dibidang usaha. Menurut Peraturan Menteri Negara Koperasi dan Usaha Kecil Dan Menengah Nomor 35.2 /Per/M.KUKM/X/2007 tanggal 5 Oktober 2007 tentang Pedoman Standar Operasional Manajemen Koperasi Jasa Kevangan Syariah dan Unit Jasa Keuangan Syariah Koperasi, Unit Jasa Keuangan Syariah (UJKS) adalah unit usaha pada Koperasi yang kegiatan usahanya bergerak di bidang pembiayaan, investasi, dan simpanan sesuai dengan pola bagi hasil (syariah), sebagai bagian dari kegiatan usaha Koperasi yang bersangkutan. Sedangkan jika berbentuk Koperasi Jasa Keuangan Syariah maka didefinisikan sebagai koperasi yang kegiatan usahanya bergerak di bidang pembiayaan, investasi, dan simpanan sesuai pola bagi hasil (syariah).

\section{Prinsip-prinsip Unit Jasa Keuangan Syariah}

Sebagai salah satu bentuk dari lembaga kevangan syariah Unit Jasa Kevangan Syariah memiliki prinsip syariah yang melekat pada setiap lembaga kevangan syariah yang meliputi, prinsip keadilan (justice), prinsip keterbukaan dan kejujuran (transparance and fairness), dan prinsip kemitraan (partnership). (subagyo, 2015:65).

Selain itu Unit Jasa Keuangan Syariah merupakan bagian dari Koperasi Syariah sehingga prinsip-prinsip dari Koperasi Syariah juga melekat didalamnya. Adapun prinsip-prinsip Koperasi Syariah yaitu:

a. Prinsip Koperasi Syariah /Unit Jasa Keuangan Syariah dalam prinsip ekonomi islam:

1) Kekayaan adalah amanah Allah SWT. yang tidak dapat dimiliki oleh siapapun secara mutlak.

2) Manusia diberi kebebasan dalam mu'amalah selama tidak melanggar ketentuan syariah. 
Hidayatulloh, et al/Jurnal Ekonomi Syariah Teori dan Terapan Vol. 3 No. 6 Juni 2016: 460-473; PEMBERDAYAAN EKONOMI ANGGOTA UNIT JASA KEUANGAN SYARIAH MELALUI PRODUK SIMPANAN DAN PEMBIAYAAN DI UNIT SIMPAN PINJAM DAN PEMBIAYAAN SYARIAH AS-SAKINAH SURABAYA

3) Manusia merupakan wakil Allah dan pemakmur di bumi.

4) Menjunjung tinggi keadilan serta menolak setiap bentuk ribawi dan pemusatan sumber dana ekonomi pada segelintir orang atau sekelompok orang saja. (Solihin, 2010:425).

b. Prinsip Koperasi Syariah /Unit Jasa Kevangan Syariah dalam prinsip syariah islam:

1) Keanggaotaan bersifat sukarela dan terbuka.

2) Keputusan ditetapkan secara musyawarah dan dilaksanakan secara konsisten dan konsekuen.

3) Pengelolaan dilakukan secara transparan dan profesional.

4) Pembagian sisa hasil usaha dilakukan secara adil, sesuai dengan besarnya jasa usaha masing-masing anggota.

5) Pemberian balas jasa modal dilakukan secara terbatas dan profesional menurut sistem bagi hasil.

6) Jujur, amanah, dan mandiri. (Solihin, 2010:426)

\section{Tujuan Unit Jasa Keuangan Syariah}

Surat Keputusan Menteri Negara Koperasi Dan Usaha Kecil Dan Menengah Tentang Petunjuk Pelaksanaan Kegiatan Usaha Koperasi Jasa Kevangan Syariah menjelaskan tentang produk dan layanan koperasi jasa kevangan syariah/Unit Jasa Kevangan Syariah menjelaskan tentang tujuan pengembangan koperasi jasa kevangan syariah/Unit Jasa Keuangan
Syariah tepatnya pada pasal II (tujuan) diantaranya adalah:

a. Meningkatkan program pemberdayaan ekonomi, khususnya di kalangan Usaha mikro, kecil menengah dan Koperasi melalui sistem syariah.

b. Mendorong kehidupan ekonomi syariah dalam kegiatan usaha mikro, kecil dan menengah khususnya dan ekonomi Indonesia pada umumnya.

c. Meningkatkan semangat dan peran serta anggota masyarakat dalam kegiatan Koperasi Jasa Keuangan Syariah.

\section{Status Keanggotaan}

Status keanggotaan seseorang pada KJKS dan UJKS diperoleh setelah seluruh persyaratan keanggotaan dipenuhi, simpanan pokok telah dilunasi dan yang bersangkutan didaftarkan dan telah menandatangani buku daftar anggota. Standar status keanggotaan seseorang pada koperasi digolongkan sebagai berikut :

a. Anggota, yaitu seseorang yang mengajukan lamaran untuk menjadi anggota koperasi, telah memenuhi seluruh persyaratan keanggotaan koperasi sebagaimana tercantum dalam anggaran dasar dan anggaran rumah tangga koperasi, dan dikabulkan permohonannya untuk menjadi anggota.

b. Calon anggota, yaitu seseorang yang mengajukan lamaran untuk menjadi 
Hidayatulloh, et al/Jurnal Ekonomi Syariah Teori dan Terapan Vol. 3 No. 6 Juni 2016: 460-473; PEMBERDAYAAN EKONOMI ANGGOTA UNIT JASA KEUANGAN SYARIAH MELALUI PRODUK SIMPANAN DAN PEMBIAYAAN DI UNIT SIMPAN PINJAM DAN PEMBIAYAAN SYARIAH AS-SAKINAH SURABAYA

anggota koperasi, namun belum dapat melunasi simpanan pokok yang ditetapkan oleh koperasi dan belum tercatat dalam buku anggota koperasi sebagaimana tercantum dalam anggaran dasar dan anggaran rumah tangga koperasi, dan dikabulkan permohonannya untuk menjadi calon anggota. Calon anggota tidak dicantumkan dalam buku daftar anggota, namun dapat memanfaatkan jasa pelayanan koperasi. Dalam kurun waktu tiga bulan calon anggota harus menjadi anggota atau ditolak keanggotaannya.

c. Anggota kehormatan, yaitu seseorang yang karena kedudukannya diminta oleh pengurus untuk menjadi anggota kehormatan koperasi, anggota kehormatan wajib membayar simpanan pokok dan simpanan sukarela serta berperan aktif untuk kemajuan koperasi.

d. Anggota luar biasa, yaitu mereka yang berstatus warga negara Indonesia atau warga negara asing bermaksud menjadi anggota yang memiliki kepentingan kebutuhan dan kegiatan ekonomi yang dilaksanakan oleh koperasi yang bersangkutan, namun tidak dapat memenuhi syarat sebagai anggota.

Produk-Produk Unit Jasa Keuangan

\section{Syariah}

Sholihin (2010) memaparkan keputusan menteri negara koperasi dan usaha kecil dan menengah tentang petunjuk pelaksanaan kegiatan usaha koperasi jasa keuangan syariah menjelaskan tentang produk dan layanan koperasi jasa keuangan syariah/Unit Jasa Kevangan Syariah dalam beberapa bentuk, yaitu terdapat pada pasal 22 (tabungan dan simpanan), pasal 23 (pembiayaan), pasal 24 (kegiatan maal).

\section{Pemberdayaan ekonomi}

Kata pemberdayaan mengandung arti tangguh atau kuat. Secara etimologis pemberdayaan berasal dari kata daya yang berarti kekuatan atau kemampuan (Sulistiani, 2004:77). Dalam Kamus Besar Bahasa Indonesia pemberdayaan adalah upaya membuat suatu kemampuan atau berkekuatan, dengan demikian pemberdayaan ekonomi anggota merupakan upaya untuk memandirikan anggota agar memiliki kemampuan dan kekuatan dalam bidang ekonomi.

Pemberdayaan dimaknai sebagai suatu proses menuju berdaya, memperoleh daya, dan pemberian daya. Pengertian proses merujuk pada serangkaian tindakan atau langkahlangkah yang dilakukan secara kronologis sistematis yang mencerminkan tahapan upaya mengubah masyarakat yang kurang atau belum berdaya menuju keberdayaan. Proses pemberdayaan merujuk pada suatu tindakan nyata yang dilakukan secara bertahap untuk 
Hidayatulloh, et al/Jurnal Ekonomi Syariah Teori dan Terapan Vol. 3 No. 6 Juni 2016: 460-473; PEMBERDAYAAN EKONOMI ANGGOTA UNIT JASA KEUANGAN SYARIAH MELALUI PRODUK SIMPANAN DAN PEMBIAYAAN DI UNIT SIMPAN PINJAM DAN PEMBIAYAAN SYARIAH AS-SAKINAH SURABAYA

mengubah kondisi masyarakat yang lemah, baik knowledge, attitude, maupun practice menuju pada penguasaan pengetahuan, sikap perilaku sadar, ketermpilan, dan kecakapan mental jasmani dan rohani (Sulistiani, 2004:77).

$$
\text { Dengan demikian konsep }
$$

pemberdayaan dapat diartikan sebagai upaya untuk membangun daya (masyarakat) dengan mendorong, memotivasi, dan membangkitkan kesadaran akan potensi yang dimilikinya serta berupaya untuk mengembangkannya. Sedangkan

Ekonomi adalah segala kegiatan ekonomi dan upaya masyarakat untuk memenuhi kebutuhan hidupnya (basic need) yaitu sandang, pangan, papan, kesehatan dan pendidikan. Sehingga dapat dipahami bahwa pemberdayaan ekonomi merupakan satu upaya untuk meningkatkan kemampuan atau potensi masyarakat dalam kegiatan ekonomi guna memenuhi kebutuhan hidup serta meningkatkan kesejahteraan mereka dan dapat berpotensi dalam proses pembangunan nasional.

\section{Indikator pemberdayaan ekonomi}

Salah satu indikator telah berdayanya perekonomian adalah terlaksananya kegiatan ekonomi tersebut dengan baik, yaitu meningkatnya produksi serta meningktanya atau terpenuhinya konsumsi dari anggota/masyarakat tersebut. Pengembangan ekonomi dalam islam mengidikasikan bahwa perhatian islam terhadap bidang ekonomi merupakan bagian dari syariah yang menjadi tuntutan dalam upaya pemeliharaan sumber-sumber ekonomi dan pengembangannya, meningkatkan kemampuan produksi dengan mengembangkan sistem dan metodenya, dan hal-hal lain yang menjadi tuntutan dalam merealisasikan kesejahteraan ekonomi umat, memenuhi kebutuhan yang mendasar, dan memerangi kemiskinan (Sholihan, 2006:393).

Menurut Ginandjar Kartasasmita (1996), pemberdayaan ekonomi rakyat adalah Upaya yang merupakan pengerahan sumber daya untuk mengembangkan potensi ekonomi rakyat untuk meningkatkan produktivitas rakyat sehingga, baik sumber daya manusia maupun sumber daya alam di sekitar keberadaan rakyat, dapat ditingkatkan produktivitasnya.

Dengan demikian penulis dapat menyimpulkan bahwa terdapat dua faktor yang dapat dijadikan indikator atau sebagai tolak ukur sebuah perekonomian anggota/masyarakat dikatakan telah berdaya atau tidak, yaitu:

a. Meningkat atau terpenuhinya konsumsi.

b. Meningkatnya produksi.

\section{METODE PENELITIAN}

\section{Pendeketan penelitian}

Penelitian ini menggunakan pendekatan kuaalitatif. Penelitian ini dilaksanakan dengan harapn mampu 
Hidayatulloh, et al/Jurnal Ekonomi Syariah Teori dan Terapan Vol. 3 No. 6 Juni 2016: 460-473; PEMBERDAYAAN EKONOMI ANGGOTA UNIT JASA KEUANGAN SYARIAH MELALUI PRODUK SIMPANAN DAN PEMBIAYAAN DI UNIT SIMPAN PINJAM DAN PEMBIAYAAN SYARIAH AS-SAKINAH SURABAYA

menjawab pertanyaann : bagaimana peran produk simpanan dan pembiayaan dalam pemberdayaan ekonomi anggota unit jasa keuangan syariah?

Penelitian ini menggunakan strategi studi kasus. Menurut Yin (2013:1) metode studi kasus adalah strategi yang lebih cocok bila pokok pertanyaan suatu penelitian berkenaan dengan "how" dan "why", bila peneliti hanya sedikit memiliki peluang untuk mengontrol peristiwaperistiwa yang akan diselidiki, dan bila mana fokus penelitian terletak pada fenomena masa kini didalam konteks kehidupan nyata.

\section{Ruang Lingkup Penelitian}

Rumusan masalah menjadi acuan peneliti dalam menentukan ruang lingkup penelitian ini. Adanya ruang lingkup penelitian ini sebagai batasan saat dilakukannya penelitian dengan harapan mampu menjawab rumusan masalah yang penulis buat untuk terpenuhinya tujuan penelitian yaitu bagaimana peran produk simpanan dan pembiayaan dalam pemberdayaan ekonomi anggota unit jasa keuangan syariah?

\section{Jenis dan Sumber data}

Adapun data yang diperlukan dalam penelitian ini adalah data primer (utama) dan dan data sekunder (penunjang). Data primer dapat diperoleh melalui wawancara secara langsung terhadap objek terkait. Sedangkan data sekunder dapat diperoleh dengan cara membaca dan mengumpulkan literatur- literatur yang berkaitan dengan topik penelitian.

\section{Unit Analisis}

Dalam unit analisis ini Peneliti menggunakan teknik purposive sampling dalam menentukan informan dari penelitian. Dalam penelitian ini unit analisis adalah anggota unit simpan pinjam dan pembiayaan syariah as-sakinah surabaya yang mengikuti program pemberdayaan anggota dengan menggunakan produk kevangan yang ditawarkan, yaitu produk simpanan dan produk pembiayaan.

\section{Pengumpulan data}

Langkah-langkah memperoleh data adalah sebagai berikut :

a. Menyelesaikan birokrasi dan surat ijin penelitian pada Fakultas Ekonomi Dan Bisnis Universitas Airlangga.

b. Mendatangi objek penelitian dan melakukan wawancara terhadap informan terkait.

\section{Teknik Analisis Data}

Adapun teknik analisa data yang digunakan adalah teknik penjodohan pola (pattern matching), yaitu logika penjodohan adalah membandingkan pola yang didasarkan atas empiris dengan pola yang diprediksikan (Yin, 2013: 140). Dalam hal ini peneliti melakukan perbandingan antara teori empiris yang terdapat pada bab sebelumnya dan proposisi yang telah dibuat dengan data yang diperoleh dari hasil wawancara terhadap informan yaitu angggota dari Unit Simpan Pinjam Dan 
Hidayatulloh, et al/Jurnal Ekonomi Syariah Teori dan Terapan Vol. 3 No. 6 Juni 2016: 460-473; PEMBERDAYAAN EKONOMI ANGGOTA UNIT JASA KEUANGAN SYARIAH MELALUI PRODUK SIMPANAN DAN PEMBIAYAAN DI UNIT SIMPAN PINJAM DAN PEMBIAYAAN SYARIAH AS-SAKINAH SURABAYA

Pembiayaan Syariah. Semakin besar persamaan antara kedua pola tersebut maka semakin menguatkan pula pada validitas internal studi kasus yang bersangkutan.

\section{Hasil Dan Pembahasan}

Unit simpan pinjam dan pembiayaan syariah As-Sakinah dinilai dapat memberikan sumbangsih yang besar pagi para anggotanya, pemberdayaan tersebut dikemas dalam bentuk produk keuangan yaitu produk simpanan dan produk pembiayaan dengan berbagai variasi. Adapun bentuk variasi dari produk simpanan antara lain adalah simpanan lancar (simpanan sakinah dan simpanan barokah), simpanan terencana (sakinah tabungan arofah, simpanan fitrah terencana, sakinah tabungan qurban, simpanan tarbiyah, simpanan walimah terencana, dan simpanan mashlahah terencana), sakinah deposito (deposito hasanah dan deposito mudharabah). Sedangkan variasi dari produk pembiayaan adalah pembiayaan modal kerja, pembiayaan multijasa, dan pembiayaan multiguna. Variasi-variasi dan model produk tersebut dibuat tentunya dengan tujuan dan manfaat yang berbeda bagi anggotaanggota Koperasi Pesantren Hidayatullah As-Sakinah.

Di suatu sisi, motivasi atau upaya mensejahterakan anggota melalui produk-produk keuangan yang ada adalah saling tolong-menolong dalam memenuhi kebutuhan serta bersamasama menjalankan aktivitas ekonomi yang sesuai dengan syariat islam sehingga visi ibadah juga akan terlaksana dengan baik. Adapun hal tersebut sesuai dengan sabda Rasulullah SAW sebagai berikut: Dari Abu Hurairah RA, ia berkata : Rasulullah SAW bersabda, "Barangsiapa meringankan satu kesusahan orang mukmin dari kesusahan-kesusahannya di dunia, maka Allah akan meringankan satu kesusahan dari kesusahan-kesusahan pada hari qiyamat. Barangsiapa memberi kemudahan kepada orang yang dalam kesulitan, Allah akan memberi kemudahan kepadanya di dunia dan di akhirat. Barangsiapa menutup aib orang muslim, maka Allah akan menutup aibnya di dunia dan di akhirat. Dan Allah selalu menolong hamba-Nya selama hamba itu suka menolong saudaranya"(HR. Muslim).

Serta firman Allah SWT pada QS. AlMaidah : 2 yaitu:

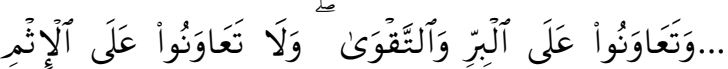

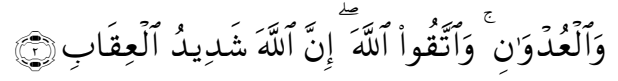

wata'a@wanu 'alal birriwat taqwa@wala@ ta'a@wanu@ 'alal ithmi wal'udwa@ni wattaqulla@hainnalla@hashadi@dul 'iqa@bi.

Artinya: "... Dan tolong-menolonglah kamu dalam (mengerjakan) kebajikan dan takwa, dan jangan tolong-menolong dalam berbuat dosa dan pelanggaran. dan bertakwalah kamu kepada Allah, Sesungguhnya Allah Amat berat siksaNya"(Al-Maidah : 2)

Melaui produk simpanan yang digunakan terutama dengan model 
Hidayatulloh, et al/Jurnal Ekonomi Syariah Teori dan Terapan Vol. 3 No. 6 Juni 2016: 460-473; PEMBERDAYAAN EKONOMI ANGGOTA UNIT JASA KEUANGAN SYARIAH MELALUI PRODUK SIMPANAN DAN PEMBIAYAAN DI UNIT SIMPAN PINJAM DAN PEMBIAYAAN SYARIAH AS-SAKINAH SURABAYA

simpanan terencana, para anggota dapat dengan mudah merealisasikan berbagai keinginan yang di rencanakan sebelumnya, dengan produk ini anggota merasa terbantu dalam mengatur pemasukaan maupun pengelurannya, sehingga beban mereka dalam memenuhi keingginannya merasa diringankan dengan adanya program simpanan dengan model seperti ini. Begitu pula dengan model-model simpanan yang lainnya yang dinilai dapat membantu anggota dalam memeberdayakan ekonomi mereka, hal ini dapat diihat dengan meningkatnya konsumsi anggota ketika atau setelah simpanan tersebut jatuh tempo untuk dibagikan.

Sedangkan dalam produk pembiayaan anggota tidak hanya menggunakannya untuk menambah modal usaha mereka, melainkan terdapat pula beberapa anggota yang menggunakannya untuk memenuhi kebutuhan yang mereka inginkan, seperti halnya dalam pengadaan barang yang difasilitasi oleh Koperasi Pesantren atau Unit Simpan Pinjam Dan Pembiayaan Syariah As-Sakinah yang kemudian dalam sistem pengembaliannya anggota dapat mengangsur pembayarannya kepada pihak Koperasi Pondok Pesantren yang berkaitan, yaitu Unit Simpan Pinjam Dan Pembiayaan Syariah As-Sakinah. Seperti halnya produk simpanan, produk pembiayaan juga berperan dalam memberdayakan ekonomi setiap anggota yang menggunakannya. Hal ini dapat dilihat dari peningkatan produksi maupun omzet usaha yang dijalani anggota serta meningkatnya konsumsi melalui produk pembiayaan dengan model pembiayaan multiguna dan pembiayaan multijasa.

Dari sembilan orang anggota yang peneliti wawancarai, satu orang menggunakan produk simpanan, dua orang menggunakan produk pembiayaan, dan enam orang lainnya menggunakan produk simpanan dan pembiayaan.

\section{Pemberdayaan ekonomi melalui produk simpanan}

Produk simpanan dapat dikatakan berperan dalam pemberdayaan ekonomi anggota koperasi pesantren. Sebagai tolak ukurnya adalah meningkatnya konsumsi setiap informan yang menggunakannya, walaupun tidak semua konsumsi informan mengalami peningkatan secara drastis namun mereka sangat merasa terbantu dengan adanya produk simpanan ini. Dengan berbagai inovasi produk simpanan yang di tawarkan, setiap informan dapat dengan mudah merealisasikan kebutuhan yang diingikan atau kebutuhan yang telah direncanakan sebelumnya tanpa merasa terbebani dengan berat karena dengan produk simpanan yang digunakan akan menambah tanggunggun jawab dari informan yaitu 
Hidayatulloh, et al/Jurnal Ekonomi Syariah Teori dan Terapan Vol. 3 No. 6 Juni 2016: 460-473; PEMBERDAYAAN EKONOMI ANGGOTA UNIT JASA KEUANGAN SYARIAH MELALUI PRODUK SIMPANAN DAN PEMBIAYAAN DI UNIT SIMPAN PINJAM DAN PEMBIAYAAN SYARIAH AS-SAKINAH SURABAYA

kewajiban untuk membayar angsuran dalam setiap bulannya sesuai dengan model yang dipilih yang manfaat serta keuntungannya dapat dirasakan setelah jatuh tempo atau tabungan tersebut telah dapat dibagikan oleh USPPS As-Sakinah karena telah mencapai target yang diharapkan oleh anggota. setiap model memiliki fungsi, keuntungan serta mafaat yang berbeda antara satu dengan lainnya. dengan produk simpanan ini simpanan ini pula manajemen kevagan anggota dapat tertata dengan rapi karena pada dasarnya orientasi dari produk simpanan ini memang mengharapkan agar setiap anggota memiliki manajemen keuangan atau tatanan keuangan yang baik.

Pemberdayaan ekonomi melalui produk simpanan

1. Pembiayaan Modal Usaha

Terdapat empat orang dari informan yang menggunakan pembiayaan yang diterimanya untuk menambah modal usaha yang dijalani. Dengan pembiayaan tersebut informan merasa dapat meningkatkan usahanya, baik dari segi output maupun laba yang didapatkan, walaupun masih ada beberapa usaha yang mengalami peningkatan yang belum begitu signifikan namun dengan pembiayaan tersebut informan sangat merasa terbantu dalam meningkatkan usahanya maupun

dalam memperbaiki

kondisi perekonomiannya.

2. Pembiayaan konsumtif

Dalam pembiayaan konsumtif terdapat dua variasi atau model pembiayaan, yaitu pembiayaan sakinah multiguna dan pembiayaan sakinah multijasa. Pembiayaan sakinah multiguna diperuntukkan bagi anggota dalam memenuhi kebututannya dengan sistem pengadaan barang, sedangkan pembiayaan sakinah multijasa merupakan pembiayaan untuk membantu anggota memenuhi kebutuhannya namun bukan dalam bentuk pengadaan barang, melainkan dalam bentuk jasa.

Selanjutnya, informan yang peneliti temui tidak satupun yang menggunakan poduk multijasa, semua informan menggunakan produk pembiayaan multiguna, rata-rata dari mereka menggunakannya dalam bentuk pengadaan barang yang mereka butuhkan. Dengan demikian atas data yang didapat oleh para informan bahwa unit simpan pinjam dan pembiayaan syariah As-Sakinah berperan dalam pemberdayaan ekonomi anggota salah satunya adalah pemenuhan kebutuhan konsumsi mereka pengadaan barang melalui pembiayaan sakinah mulitiguna. 
Hidayatulloh, et al/Jurnal Ekonomi Syariah Teori dan Terapan Vol. 3 No. 6 Juni 2016: 460-473; PEMBERDAYAAN EKONOMI ANGGOTA UNIT JASA KEUANGAN SYARIAH MELALUI PRODUK SIMPANAN DAN PEMBIAYAAN DI UNIT SIMPAN PINJAM DAN PEMBIAYAAN SYARIAH AS-SAKINAH SURABAYA

Penjelasan diatas menunjukkan keberhasilan unit simpan pinjam dan pembiayaan syariah As-Sakinah surabaya dalam memberdayakan ekonomi anggotanya melalui berbagai inovasi atau model-model peroduk keuangan yang ditawarkan. Penjelasan tersebut juga diperkuat oleh informan yang dipilih dihak USPPS As-Sakinah, dalam hal ini peneliti memilih manajer USPPS karena dirasa informan ini adalah orang yang mengerti seluk-beluk unit yang dipimpinnya secara mendalam. Informan berpendapat bahwa unit simpanpinjam dan pembiayaan syariah As-Sakinah telah berperan dalam upaya memberdayakan ekonomi anggota melalui produk pembiayaan yang dirasa dapat memperkuat modal usaha anggota yang nantinya akan meningkatkan produksinya, disisi lain USPPS As-Sakinah juga memberikan pendampingan bagi anggota yang akan memulai usaha baru atau anggota yang telah memiliki usaha yang nantinya USPPS juga akan membantu dalam memasarkan produk dari usaha anggota melalui usaha ritel yang juga dimiliki Koperasi Pondok Pesantren Hidayatullah yaitu Swalayan AsSakinah. Demikian pula pada produk simpanan yang juga dinilai dapat membantu anggota dalam memberdayakan atau meningkatkan perekonomiannya, hal ini terlihat dengan terpenuhi atau meningkatnya konsumsi anggota, karena pada dasarnya orientasi dari produk ini adalah salah satunya untuk membantu para anggota dalam hal manajemen keuangan mereka.

\section{SIMPULAN}

Berdasarkan hasil dari pembahasan sebelumnya dapat disimpulkan bahwa Unit Simpan Pinjam Dan Pembiayaan Syariah As-Sakinah berperan dalam pemberdayaan ekonomi anggota melalui berbagai produk jasa keuangan yang ditawarkan. Produk-produk tersebut berupa simpanan dan pembiayaan dengan berbagai variasi dan model yang memiliki fungsi dan manfaat yang berbeda antara satu produk dengan produk lainnya. Produk pembiayaan terbagi dalam dua kategori yaitu pembiayaan modal usaha dan pembiayaan konsumtif. Pembiayaan modal usaha dapat membantu anggota yang hendak memulai usaha baru maupun anggota yang telah memiliki usaha namun masih membutuhkan tambahan dana atau tambahan modal, sedangkan pembiayaan konsumtif diberikan kepada anggota untuuk pemenuhan kebutuhannya di sektor konsumsi salah satunya dengan pengadaan barang atau jasa oleh pihak Koperasi Pondok Pesantren. Begitu pula dengan produk simpanan, produk ini pada dasarnya diterapkan dengan tujuan membantu anggota dalam hal manajemen kevangan sehingga kevangan anggota dapat tertata dengan baik dan rapi. 
Hidayatulloh, et al/Jurnal Ekonomi Syariah Teori dan Terapan Vol. 3 No. 6 Juni 2016: 460-473; PEMBERDAYAAN EKONOMI ANGGOTA UNIT JASA KEUANGAN SYARIAH MELALUI PRODUK SIMPANAN DAN PEMBIAYAAN DI UNIT SIMPAN PINJAM DAN PEMBIAYAAN SYARIAH AS-SAKINAH SURABAYA

Pemberdayaan melalui produk pembiayaan modal kerja memiliki dampak yang positif bagi usaha yang dimiliki informan yaitu dapat meningkatkan output maupun pendapatan mereka walaupun peningkatannya belum begitu signifikan, begitu pula dalam pembiayaan konsumtif, informan merasa sangat terbantu dalam pemenuhan kebutuhan yang diinginkan salah satunya dengan pengadaan barang oleh pihak USPPS. Sedangkan produk simpanan yang memang pada dasarnya dibuat sebagai sarana untuk membantu anggota dalam manajemen kevangannya dirasakan memiliki peran positif bagi informan, terutama dapat membantu mereka dalam merealisasikan kebutuhan atau keinginan yang telah direncanakan sebelumnya serta dapat membantu mereka dalam mengelola keuangan guna memperbaiki bahkan meningkatkan perekonomian mereka.

\section{DAFTAR PUSTAKA}

Departemen Pendidikan
Kebudayaan. 1993. Kamus
Bahasa Indonesia Jakarta: Balai
Pustaka.

Departemen Agama Republik Indonesia. 2006. Al-quran Dan Terjemahannya. Jakarta: CV. Pustaka Agung Harapan.

$\begin{array}{ccr}\text { Kartasasmita, } & \text { Ginandjar. } & 1996 . \\ \text { Pembangunan } & \text { Untuk } & \text { rakyat. }\end{array}$

Memadukan pertumbuhan dan pemerataan. (Online), (www.ginandjar.com, diakses 14 November 2015).

Koperasi Pesantren Hidayatulloh AsSakinah.http://kpphassakinah.com.

(Online), diakses pada 7 Januari 2016. Republik Indonesia. Peraturan Menteri Negara Koperasi dan Usaha Kecil dan Menengah Republik Indonesia Nomor :91/Kep/M.KUKM/IX/2004. 2004. (Online),

(http://www.depkop.go.id.html, diakses 12 November 2015).

$\begin{array}{lrr}\text { Usaha Kecil Dan Menengah. } & 2007 . \\ \text { Peraturan } & \text { Nomor: } & 35.2 \\ \text { /Per/M.KUKM/X/2007. } & \text { Tentang } \\ \text { Pedoman Standar } & \text { Operasional } \\ \text { Manajemen Koperasi Jasa Kevangan } & \text { Kan } \\ \text { Syariah Dan Unit Jasa } & \text { Keuangan } \\ \text { Syariah Koperasi. } & \text { (online) } \\ \text { www.depkop.go.id, diakses pada 12 } \\ \text { November 2015. }\end{array}$
- Menteri Negara Koperasi Dan Usaha Kecil Dan Menengah Republik Indonesia. 2007. Peraturan Nomor: 35.3/Per/M.KUKM/X/2007. Tentang Pedoman Penilaian Kesehatan Koperasi Jasa Keuangan Syariah Dan Unit Jasa Kevangan Syariah Koperasi. Undang-undang Republik Indonesia No. 10 Tahun 1998 tentang Perbankan.

Undang-undang Republik
Indonesia No. 10 Tahun 1998 tentang
Perbankan. Undang-undang Republik


Hidayatulloh, et al/Jurnal Ekonomi Syariah Teori dan Terapan Vol. 3 No. 6 Juni 2016: 460-473; PEMBERDAYAAN EKONOMI ANGGOTA UNIT JASA KEUANGAN SYARIAH MELALUI PRODUK SIMPANAN DAN PEMBIAYAAN DI UNIT SIMPAN PINJAM DAN PEMBIAYAAN SYARIAH AS-SAKINAH SURABAYA

Indonesia No. 10 Tahun 1998 tentang

Perbankan.

Santoso. Fiqih. (2008). Concept and Method for Community Empowerment Indonesia,

http://appreciativeorganization.wordpr ess.com. (Online), diakses pada 16 Januari 2016

Sholihan, H. Asmuni. 2006. Fikih Ekonomi Umar Bin Al-Khattab. Jakarta: Khaifah.

Solihin, Ahmad Ifham. 2010. Pedoman Umum Lembaga Kevangan Syariah. Jakarta: Kompas gramedia. 2010. Buku Pintar Ekonomi Syariah. Jakarta: Gramedia pustaka utama.

Subagyo, Ahmad. 2015. Keuangan Mikro Syariah. Jakarta: Mitra wacana media.

Sulistiani, Ambar Teguh. 2004. Kemitraan Dan Model-Model Pemberdayaan. Jogjakarta: Gava Media.

Yin, Robert K. 2013. Studi kasus: desain dan metode. Jakarta: Rajawali Press. 